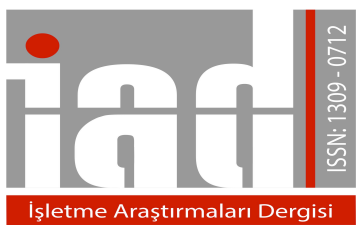

www.isarder.org

\title{
Evaluating The Financial Performances Of Privately Owned Deposit Banks In Turkey By Topsis Method
}

\author{
Ceren ORAL \\ Mugla Sitk1 Kocman University \\ Fethiye Faculty of Management \\ Department of Economics and Finance \\ Fethiye-Mugla, Turkey \\ ceren.uzar@gmail.com
}

\begin{abstract}
The measurement of financial performance, TOPSIS method is often used in many sectors. Evaluation of the performance of the banking sector with the financial and economic development has become a necessity in terms of competitiveness. The aim of this study is to evaluate privately owned deposit banks in the financial performance of the year 2012-2014 operating in Turkey by multi-criteria decisionmaking methods of TOPSIS (Technique for Order Preference by Similarity to Ideal Solutions). In the analysis; making use of the most commonly used criteria in the literature given equal weights to these criteria and performance scores were obtained.
\end{abstract}

Keywords: TOPSIS Method, Financial Performance Analysis, Banking Sector

\section{Introduction}

Multi-criteria decision-making methods have been successfully applied in many fields. In different performance criteria and taking into account in calculating the weight, it is referred to the method that uses several quantitative and qualitative data (Cristóbal, 2012, p. 752). One of the multi-criteria decision-making methods TOPSIS methods, proximity to the ideal solution is based on the main principles of the decision point. The method helps to compare the alternative options based on the ideal state of maximum and minimum values that can be taken in accordance with certain criteria and benchmarks (Saldanlı and Sirma, 2014, p. 186).

In TOPSIS method, businesses are using financial ratios derived score data as in the nature of financial performance and ranking is made between alternatives. Thus, the alternative chosen by decision-makers, the ideal outcome is the closest and most distant alternate negative-ideal results were determined. The most important component of the financial sector is the banks and the banking sector. An important part of the flow of funds is done through banks. In this sense; the assessment of the performance of the banks has a great importance. 
In this study, in the financial services industry, the performance of privately owned deposit banks operating in Turkey is analyzed and TOPSIS method is used as analysis methods. In this study, the study of literature is given after the introduction, TOPSIS method and the method of implementation are described. In the implementation part of the study privately owned deposit banks operating in Turkey are ranked according to their performance. Ten banks in the study were evaluated by ten criteria. Equal weight is given to each criterion. In the conclusion, the findings have been reviewed.

\section{Literature Review}

TOPSIS method for the measurement of financial performance, are frequently used in many sectors. Due to the ease it provides to all those involved in the decisionmaking points, it founds applications in the finance literature. Studies performed by using TOPSIS method are summarized below.

TOPSIS method has been shown by reference of Hwang and Yoon's (1981) works by Chen and Hwang (1992).

Feng and Wang (2000) studied the performance of five airline companies operating in Taiwan with TOPSIS Method.

$\mathrm{Wu}$ and Olson (2006), made in their study, the Canadian bank's financial performance is evaluated according to 12 financial ratios using TOPSIS method. The results were compared with data mining methods.

Alptekin and Ş1klar (2009), in their study, were evaluated the performance of Turkey shares during the period January 2007-December 2008 which is an important investment vehicle for pension funds in terms of individual investors by TOPSIS method.

Demireli (2010) was trying to determine the performance of state-owned banks operating in Turkey by using TOPSIS method.

Dumanoglu (2010) in the study has evaluated 2004-2009 ISE registered financial performance of 15 cement companies, with the aid of the balance sheet and income statement data by using TOPSIS method with the help of eight financial ratios.

Karimi, Yusap and Law (2010) in their study were carried out the sorting of the suitability for foreign direct investments of the countries forming the Association of Southeast Asian Nations (ASEAN) by using the TOPSIS method.

Loaders and Attack (2010) in their study, they aim to evaluate the operating performance of financial performance according to different criteria.

El-Santawyve and Ahmed (2012) made in their study, 5 pieces of performance consulting firm made according to four basic criteria in line with TOPSIS method was put into this ranking consulting firms.

Hossein et al. (2013), have conducted a study to compare scores obtained in the best performing businesses Tehran Stock Exchange from 2009 to 2011, with financial ratios by AHP-TOPSIS method.

Yılmaz and Çağıl (2012), in their study, the years 2007-2010 registered to ISE and Information Sector twelve companies operating in the financial performance are evaluated by applying TOPSIS method, using 8 financial ratios. 
Yayar and Baykara (2012) have attempted to measure effectiveness and efficiency of activities between 2005-2011 participation banks operating in Turkey by using the TOPSIS method in their studies.

\section{Research Methodology}

TOPSIS is a popular technique used for rank ordering units by preference or similarity to ideal solution. The underlying logic of TOPSIS is rooted in the ideal solution and the negative ideal solution. Ideal solution is consisted of all best values accessible of criteria, whereas negative ideal solution is consist of all worst values (Mukherjee and Nath, 2005, p. 175).

TOPSIS has numerous advantages. It has a simple process. It is easy to use and programmable. The number of steps remains unchanged in any case the number of attributes (Velasquez and Hester, 2013, p. 62). The main steps of TOPSIS method are the following (Hwang and Yoon, 1981):

Step 1: Construct normalized decision matrix: This step transforms various attribute dimensions into non-dimensional attributes, which allows comparisons across criteria. Normalize scores or data as follows:

$\mathrm{r}_{\mathrm{ij}}=\mathrm{x}_{\mathrm{ij}} /\left(\sum \mathrm{x}^{2}{ }_{\mathrm{ij}}\right)$ for $\mathrm{i}=1, \ldots, \mathrm{m} ; \mathrm{j}=1, \ldots, \mathrm{n}$

Step 2: Construct the weighted normalized decision matrix: Assume we have a set of weights for each criteria $\mathrm{w}_{\mathrm{j}}$ for $\mathrm{j}=1, \ldots \mathrm{n}$. Multiply each column of the normalized decision matrix by its associated weight. An element of the new matrix is:

$\mathrm{V}_{\mathrm{ij}}=\mathrm{w}_{\mathrm{j}} \mathrm{r}_{\mathrm{ij}}$

Step 3: Decide the ideal and negative ideal solutions:

Ideal solution: $A^{*}=\left\{v 1^{*}, \ldots, v n^{*}\right\}$, where $v^{*}=\left\{\max (v i j)\right.$ if $j \in J ; \min (v i j)$ if $\left.j \in J^{\prime}\right\}$

Negative ideal solution: $A^{\prime}=\left\{v 1^{\prime}, \ldots, v n^{\prime}\right\}$, where $v^{\prime}=\{\min (v i j)$ if $j \in J ; \max (v i j)$ if $\left.\mathrm{j} \in \mathrm{J}^{\prime}\right\}$

Step 4: Calculate the Separation Measures for Each Alternative:

The separation from the ideal alternative is:

$$
\mathrm{S}_{\mathrm{i}}{ }^{*}=\left[\Sigma\left(\mathrm{v}_{\mathrm{j}}{ }^{*}-\mathrm{v}_{\mathrm{ij}}\right)^{2}\right]^{1 / 2} \quad \mathrm{i}=1, \ldots, \mathrm{m}
$$

Similarly, the separation from the negative ideal alternative is:

$\mathrm{S}_{\mathrm{i}}^{\prime}=\left[\Sigma\left(\mathrm{v}_{\mathrm{j}}^{\prime}-\mathrm{v}_{\mathrm{ij}}\right)^{2}\right]^{1 / 2} \quad \mathrm{i}=1, \ldots, \mathrm{m}$

Step 5: Calculate the relative closeness to the ideal solution $\mathrm{C}_{\mathrm{i}}^{*}$

$\mathrm{C}_{\mathrm{i}}^{*}=\mathrm{S}_{\mathrm{i}}^{\prime} /\left(\mathrm{S}_{\mathrm{i}}^{*}+\mathrm{S}_{\mathrm{i}}^{\prime}\right), 0<\mathrm{C}_{\mathrm{i}}^{*}<1$, and we must select the alternative with $\mathrm{Ci}^{*}$ closest to 1.

The purpose of this study is to evaluate the financial performance of privately owned deposit banks in Turkey with the help of TOPSIS method, between the periods of 2012-2014. Data were obtained The Banks Association of Turkey's website (www.tbb.org.tr).

According the availability of data, there are eleven privately owned deposit banks. These banks are: Adabank, Akbank, Anadolubank, Fibabanka, Şekerbank, Tekstilbank, Turkishbank, Teb, Garantibank, İşbank and Yapıkredibank. However, the bank devolved to Savings Deposit Insurance Fund (SDIF) was not included in the study.

During analysis stage of the study; in terms of confidentiality of performance data's about banks, codes were used instead of the names of the banks. The codes of 
privately owned deposit banks are respectively B1, B2, B3, B4, B5, B6, B7, B8, B9, $\mathrm{B} 10$ and $\mathrm{B} 10$.

To measure the financial performance of the bank; the bank's capital adequacy, asset quality, liquidity, profitability, revenue and expenditure structure is utilized as giving information about structure and enables the assessment of the financial statements by establishing a relationship between the relative financial ratios. For this purpose; benefiting from most of the criteria used in the literature, these criteria are given equal weight, performance scores were obtained.

The effects of the financial performance of these criteria are weighted as one for the sum and coefficients were determined. The equal weights are given for each of ten criteria because ratios are of the same significance for this paper. So, the equal weight for each one is determined as 0,1 .

Ten banks in the study were evaluated by ten criteria. Financial criteria's and the weights of criteria's are shown in the Table 1.

Table 1: The Weight of Financial Criteria's

\begin{tabular}{|l|l|l|}
\hline Codes & Criterias & Weights \\
\hline C1 & Equity/Total Assets & 0,1 \\
\hline C2 & Financial Assets (net)/Total Assets & 0,1 \\
\hline C3 & Total Credits and Receivables/Total Assets & 0,1 \\
\hline C4 & Pre-Tax Profit/Total Assets & 0,1 \\
\hline C5 & Liquid Assets/Total Assets & 0,1 \\
\hline C6 & Liquid Assets/ Short Term Liabilities & 0,1 \\
\hline C7 & Term Net Profit- Loss/ Total Assets & 0,1 \\
\hline C8 & Term Net Profit- Loss/Total Equity & 0,1 \\
\hline C9 & Net Interest Income/Total Assets & 0,1 \\
\hline C10 & Net Interest Income/Total Operating Income & 0,1 \\
\hline
\end{tabular}

4. Research Findings

In the application of TOPSIS method, Standard Decision Matrix was formed in the first stage. Table 2 shows the standardized decision matrix for the year 2012.

Table 2: Standardized Decision Matrix for the Year 2012

\begin{tabular}{|l|l|l|l|l|l|l|l|l|l|l|}
\hline & \multicolumn{1}{l}{ Criterias } & \multicolumn{10}{l|}{ C1 } & C2 & C3 & C4 & C5 & C6 & C7 & C8 & C9 & C10 \\
\hline B1 & 14,1 & 29,6 & 56,2 & 2,4 & 39,7 & 71,2 & 1,9 & 13,5 & 2,9 & 58,2 \\
\hline B2 & 18,4 & 13,7 & 66,4 & 3,3 & 27,9 & 45,8 & 2,6 & 14,3 & 5,6 & 69,6 \\
\hline B3 & 9,8 & 3,9 & 82,6 & 1,5 & 16,3 & 38,2 & 1,2 & 11,9 & 3,1 & 66,7 \\
\hline B4 & 12,6 & 14,9 & 68,7 & 2,1 & 19,6 & 35,7 & 1,7 & 13,2 & 4 & 46,1 \\
\hline B5 & 15,6 & 9 & 72,4 & 0,9 & 22 & 37,2 & 0,7 & 4,7 & 3,1 & 63,9 \\
\hline B6 & 17,3 & 7,6 & 41,4 & 0,2 & 51,8 & 68,6 & 0,2 & 0,9 & 2,7 & 64 \\
\hline B7 & 11 & 11,2 & 68,2 & 1,5 & 26,9 & 52,5 & 1,1 & 10,1 & 3,9 & 71,1 \\
\hline B8 & 13,3 & 24 & 57,3 & 2,4 & 38 & 64,5 & 1,9 & 14,4 & 3,1 & 57,3 \\
\hline B9 & 12,9 & 22 & 61,1 & 2,3 & 25,7 & 46,2 & 1,9 & 14,6 & 3 & 54,3 \\
\hline B10 & 13,8 & 17,6 & 62 & 2 & 26,4 & 51,5 & 1,6 & 11,3 & 3 & 55 \\
\hline
\end{tabular}


After standardized decision matrix is created, normalization of these values is calculated. Table 3 shows the normalized decision matrix for the year 2012 .

Table 3: Normalized Decision Matrix for the Year 2012

\begin{tabular}{|c|c|c|c|c|c|c|c|c|c|c|}
\hline & \multicolumn{10}{|c|}{ Criterias } \\
\hline & $\mathrm{C} 1$ & $\mathrm{C2}$ & $\mathrm{C3}$ & $\mathrm{C4}$ & $\mathrm{C5}$ & C6 & $\mathrm{C7}$ & $\mathrm{C8}$ & C9 & $\mathrm{C} 10$ \\
\hline B1 & 0,316 & 0,5463 & 0,2756 & \begin{tabular}{|l|}
0,3727 \\
\end{tabular} & 0,4031 & \begin{tabular}{|l|}
0,4278 \\
\end{tabular} & 0,3710 & \begin{tabular}{|l|}
0,3639 \\
\end{tabular} & 0,2592 & 0,3013 \\
\hline B2 & 0,4125 & 28 & 0,3256 & 25 & & 752 & 0,5077 & 0,3855 & 0,5006 & \\
\hline B3 & & 0,0719 & 4050 & & & & & 208 & 771 & \\
\hline B4 & 0,2824 & 0,2750 & 0,3369 & 261 & 0,199 & 0,2145 & & 0,3558 & & \\
\hline B5 & 0,3497 & 0,1661 & 0,3550 & 397 & 0,2234 & 235 & 0,1367 & 267 & 0,2771 & \\
\hline B6 & & & & & & & & & & \\
\hline B7 & & 0,2067 & & & & & & & & \\
\hline B8 & 0,2981 & 0,4430 & 0,2810 & 0,3727 & 0,3858 & 0,3875 & 0,3710 & \begin{tabular}{|l|}
0,3882 \\
\end{tabular} & 0,2771 & 0,2967 \\
\hline B9 & & & & & & & & & & \\
\hline B10 & 0,3093 & 0,3248 & 0,3040 & 0,3106 & 0,2680 & 0,3094 & 0,3124 & \begin{tabular}{|l|}
0,3046 \\
\end{tabular} & 0,2682 & 0,2847 \\
\hline
\end{tabular}

Then, weighted normalized matrix is formed. Table 4 shows the weighted normalized matrix and positive ideal solution (PIS) and negative ideal solution (NIS) for the year 2012 .

Table 4: Weighted Normalized Matrix and Positive Ideal Solution (PIS) and Negative Ideal Solution (NIS) for the Year 2012

\begin{tabular}{|l|l|l|l|l|l|l|l|l|l|l|}
\hline & \multicolumn{1}{l}{ Criterias } & \multicolumn{10}{l|}{} \\
\hline & C1 & C2 & C3 & C4 & C5 & C6 & C7 & C8 & C9 & C10 \\
\hline B1 & 0,0316 & 0,0546 & 0,0275 & 0,0372 & 0,0403 & 0,0427 & 0,0371 & 0,0363 & 0,0259 & 0,0301 \\
\hline B2 & 0,0412 & 0,0252 & 0,0325 & 0,0512 & 0,0283 & 0,0275 & 0,0507 & 0,0385 & 0,0500 & 0,0360 \\
\hline B3 & 0,0219 & 0,0071 & 0,0405 & 0,0232 & 0,0165 & 0,0229 & 0,0234 & 0,0320 & 0,0277 & 0,0345 \\
\hline B4 & 0,0282 & 0,0275 & 0,0336 & 0,0326 & 0,0199 & 0,0214 & 0,0331 & 0,0355 & 0,0357 & 0,0238 \\
\hline B5 & 0,0349 & 0,0166 & 0,0355 & 0,0139 & 0,0223 & 0,0223 & 0,0136 & 0,0126 & 0,0277 & 0,0330 \\
\hline B6 & 0,0387 & 0,0140 & 0,0203 & 0,0031 & 0,0526 & 0,0412 & 0,0039 & 0,0024 & 0,0241 & 0,0331 \\
\hline B7 & 0,0246 & 0,0206 & 0,0334 & 0,0232 & 0,0273 & 0,0315 & 0,0214 & 0,0272 & 0,0348 & 0,0368 \\
\hline B8 & 0,0298 & 0,0443 & 0,0281 & 0,0372 & 0,0385 & 0,0387 & 0,0371 & 0,0388 & 0,0277 & 0,0296 \\
\hline B9 & 0,0289 & 0,0406 & 0,0299 & 0,0357 & 0,0260 & 0,0277 & 0,0371 & 0,0393 & 0,0268 & 0,0281 \\
\hline B10 & 0,0309 & 0,0324 & 0,0304 & 0,0310 & 0,0268 & 0,0309 & 0,0312 & 0,0304 & 0,0268 & 0,0284 \\
\hline $\boldsymbol{A}$ * & 0,0412 & 0,0546 & 0,0405 & 0,0512 & 0,0526 & 0,0427 & 0,0507 & 0,0393 & 0,0500 & 0,0368 \\
\hline $\boldsymbol{A -}$ & 0,0219 & 0,0071 & 0,0203 & 0,0031 & 0,0165 & 0,0214 & 0,0039 & 0,0024 & 0,0241 & 0,0238 \\
\hline
\end{tabular}

The distances between the valuation subjects and positive ideal and negative ideal solution are determined by taking the maximum and the minimum values for each criterion from weighted normalization matrix table. The distance of each alternative from PIS and NIS can be shown as follows:

$\mathrm{S}^{*}=(0,37815 ; 0,41806 ; 0,08001 ; 0,05932 ; 0,08267 ; 0,09290 ; 0,06528 ; 0,03920$; $0,04931 ; 0,054613)$

S- $=(0,082957 ; 0,087551 ; 0,046964 ; 0,060048 ; 0,03065 ; 0,045889 ; 0,046838 ; 0,076973$; $0,070315 ; 0,057974)$ 
Table 5 shows the final ranking of banks. Depends on the scores, the ranking of the banks regarding financial performance from top to bottom are B1, B2, B8, B9, B10, $\mathrm{B} 4, \mathrm{~B} 7, \mathrm{~B} 3, \mathrm{~B} 6$ and $\mathrm{B} 5$.

Table 5: Rankings of Banks and Performance Scores of Banks for the Year 2012

\begin{tabular}{|c|l|l|}
\hline Ranking & Banks & Scores \\
\hline 1 & B1 & 0,686890346 \\
\hline 2 & B2 & 0,676814143 \\
\hline 3 & B8 & 0,662520639 \\
\hline 4 & B9 & 0,587752449 \\
\hline 5 & B10 & 0,51492583 \\
\hline 6 & B4 & 0,503051626 \\
\hline 7 & B7 & 0,417739181 \\
\hline 8 & B3 & 0,369868854 \\
\hline 9 & B6 & 0,330636086 \\
\hline 10 & B5 & 0,27045241 \\
\hline
\end{tabular}

The same steps are made for the year 2013 and 2014. Table 6 shows the performance scores between the periods of 2012-2014.

Table 6: Rankings of Banks and Performance Scores of Banks between the periods of 2012-2014

\begin{tabular}{|c|c|c|c|c|c|c|c|c|}
\hline \multicolumn{3}{|c|}{$\mathbf{2 0 1 2}$} & \multicolumn{3}{c|}{$\mathbf{2 0 1 3}$} & \multicolumn{3}{c|}{$\mathbf{2 0 1 4}$} \\
\hline Ranking & Banks & Scores & Ranking & Banks & Scores & Ranking & Banks & Scores \\
\hline 1 & B1 & 0,686890 & 1 & B1 & 0,694329 & 1 & B1 & 0,594741 \\
\hline 2 & B2 & 0,676814 & 2 & B10 & 0,634955 & 2 & B8 & 0,542471 \\
\hline 3 & B8 & 0,662520 & 3 & B8 & 0,625443 & 3 & B9 & 0,517872 \\
\hline 4 & B9 & 0,587752 & 4 & B9 & 0,585012 & 4 & B6 & 0,483614 \\
\hline 5 & B10 & 0,514925 & 5 & B2 & 0,497231 & 5 & B2 & 0,447229 \\
\hline 6 & B4 & 0,503051 & 6 & B7 & 0,433117 & 6 & B10 & 0,396028 \\
\hline 7 & B7 & 0,417739 & 7 & B4 & 0,413645 & 7 & B4 & 0,362388 \\
\hline 8 & B3 & 0,369868 & 8 & B5 & 0,404603 & 8 & B3 & 0,357668 \\
\hline 9 & B6 & 0,330636 & 9 & B6 & 0,383913 & 9 & B7 & 0,353953 \\
\hline 10 & B5 & 0,270452 & 10 & B3 & 0,323856 & 10 & B5 & 0,265043 \\
\hline
\end{tabular}

\section{Conclusion}

The measurement of financial performance of the banks by the help of financial ratios and analyze them, is very crucial of identifying and comparability of fair value. In this study, the financial performances of the privately-owned banks operating in Turkey three years from 2012 to 2014 were analyzed. There are ten banks in the scope of analysis and ten financial ratios have taken as criteria; 2012, 2013 and 2014 were used in determining the financial performance of the bank, separately. These criteria are given equal importance. Then, the financial ratios were converted into a single score showing an overall bank performance by the help of TOPSIS method. Finally, by making sort of the banks, performance rating process is completed.

The best performing bank in 2012 is coded bank B1. B2, B8, B9, B10, B4, B7, B3, B6, B5 coded banks are followed respectively after this bank. The ranking based on 
the performance of banks in 2013 is as follows: B1, B10, B8, B9, B2, B7, B4, B5, B6, $B 3$. Finally, the performance scores of banks in the ranking of banks in 2014, it is seen to be as follows; B1, B8, B9, B6, B2, B10, B4, B3, B7 and B5.

When the results were analyzed, coded $\mathrm{B} 1$ seems to be the best performing banks in 2012-2014 periods. In 2012 bank code B2, bank code B10 in 2013, B8 code in 2014 is located as 2 nd rank. In $3^{\text {rd }}$ rank, taking into consideration in years respectively B8, B8 and B9 coded banks are located. B8 coded bank is seen as stable as good performance. Although in 2012-2013 years being in 4th rank B9coded banks is seen in 3rd rank in 2014. Despite being in $5^{\text {th }}$ rank in 2012 , B10 coded bank has a good performance in 2013 and rose to $2^{\text {nd }}$ rank but in 2014 it decreased to $6^{\text {th }}$ rank.

Due to the valuation basis of all criteria that can be evaluated together, TOPSIS method is preferred. Therefore, the study of performance indicators specified weight and performance indicators using the TOPSIS method, the performance of the privately owned deposit banks are evaluated.

Due to the rules of TOPSIS method it is weighted by certain weights. In this study, equal weight is given to each criterion because ratios are of the same significance for this paper. The weight given to these criteria by decision makers may vary in the long term. Only privately-owned deposit banks are taken into consideration in this study. All the other banks can be involved in the study and can be given different weights to different criteria and TOPSIS performance scores can be calculated in this direction. In this regard, the study showed a clear quality improvement.

\section{References}

Alptekin, N., Şıklar, E., (2009). "Türk Hisse Senedi Emeklilik Yatırım Fonlarının Çok Kriterli Performans Değerlendirmesi: Topsis Metodu”, Dumlupınar Üniversitesi Sosyal Bilimler Dergisi, Sayı:25, 185-196.

Chen, S.J., Hwang, C.L., Hwang, F.P., (1992). Fuzzy Multiple Attribute Decision Making: Methods and Applications. Lecturer Notes in Economics and Mathematical System, Springer, Verlag.

Cristóbal, J.R.S., (2012). "Contractor Selection Using Multicriteria Decision Making Methods", Journal Of Construction Engineering and Management, Vol. 138, No.6, 751-758.

Demireli, E. (2010). TOPSIS çok kriterli karar verme sistemi: Türkiye'deki kamu bankaları üzerine Bir uygulama. Girişimcilik ve Kalkınma Dergisi, 5(1), 101-112.

Dumanoğlu S., (2010). "IMKB'de İşlem Gören Çimento şirketlerinin Mali Performansının TOPSIS Yöntemi İle Değerlendirilmesi" Marmara Üniversitesi, İ.İ.B.F Dergisi, Vol.29, No:2, 323-339.

El-Santawy M. F., Ahmed A.N., (2012). "An Information Entropy Weighting Method Combined to TOPSIS Approach for Ranking Consulting Firms", Life Science Journal, Vol.9, No:1, 147-150.

Feng, C. M., Wang, R. T., (2000). "Performance Evaluation for Airlines Including the Consideration of Financial Ratios", Journal of Air Transport Management, Vol.6, 133-142. 
Hosseini, S.H., Ezazi, M.E., Heshmati, M.R., Reza, S.M., (2013). “Top Companies Ranking Based on Financial Ratio with AHP-TOPSIS Combined Approach and Indices of Tehran Stock Exchange", International Journal of Economics and Finance, Vol.5 No: 3, 126-133.

Hwang, C.L., Yoon, K., (1981). Multiple Attribute Decisions Making: Methods and Applications: A State of-the-Art-Survey. Lecture Notes in Economics and Mathematical System, Springer, Verlag.

Karimi, M. S., Yusop, Z., Law, S. H., (2010), "Location Decision for Foreign Direct Investment in ASEAN Countries: A TOPSIS Approach”, International Research Journal of Finance and Economics, Issue: 36, 196-207.

Mukherjee A., Nath P., (2005)" An Empirical Assessment of Comparative Approaches to Service Quality Measurement" Journal of Services Marketing, Vol.19, No:3, 174-184.

Saldanlı, A., Sirma, İ., (2014). “TOPSIS Yönteminin Finansal Performans Olarak Kullanılabilirliği”, Marmara Üniversitesi Öneri Dergisi, Vol. 11, No: 41, 185-202.

Velasquez, M., Hester, P.T., (2013). “An Analysis of Multi-Criteria Decision Making Methods", International Journal of Operations Research, Vol. 10, No: 2, 56-66.

Wu D., Olson, D. L., (2006). "A TOPSIS Data Mining Demonstration And Application To Credit Scoring", International Journal of Data Warehousing\& Mining, Vol. 2, No:3, 1-10.

Yayar, R., Baykara, H.V., (2012). “TOPSIS Yöntemi ile Katılım Bankalarının Etkinliği ve Verimliliği Üzerine Bir Uygulama", Business and Economics Research Journal. Vol. 3, No: 4, 21-42

Yilmaz Türkmen, S., Çağ1l, G., (2012). "IMKB’ye Kote Bilişim Sektörü Şirketlerinin Finansal Performanslarının TOPSIS Yöntemi İle Değerlendirilmesi", Maliye Finans Yazıları, Vol.26, No: 95, 59-78.

https://www.tbb.org.tr/tr/banka-ve-sektor-bilgileri/istatistiki-raporlar/59, 08.11.2015. 